\title{
LIGHTWEIGHT MORTAR GEOPOLIMER BASED ON FLY ASH AND PALM ASH
}

\author{
Edowinsyah $^{1}$, Firdaus $^{2}$ \\ ${ }^{1}$ Magister Teknik Sipil , Universitas Bina Darma, Palembang, Idnonesia \\ 2,Prodi Teknik Sipil, Universitas Bina Darma, Palembang, Idnonesia \\ Email: 1edopga18@gmail.com, ${ }^{2}$ firdaus.dr@gmail.com
}

\begin{abstract}
Abstrack
This research discusses the use of alumunium powder in the manufacture of geopolymer mortar made from fly ash and palm ash, with the aim of knowing the optimal amount of alumunium powder mixture against the compressive strength of geopolymer mortar. The research method used experimental methods in the laboratory, to examine the compressive strength of different geopolymer mortar tests used in the form of cubes measuring $5 \times 5 \times 5 \mathrm{~cm}$ with a mixture composition of $\mathrm{NaOH}: \mathrm{Na} 2 \mathrm{SiO} 3=1: 2.5$, Activator: Precursor $=1: 1$, Fine Aggregate: Precursor $=1.5: 1$ Concentration of $\mathrm{NaOH}=12 \mathrm{M}$ for the ratio of fly ash use: palm ash $=75$ : $25 \%$ using alumunium powder as much as $0,0.5,0.75$ and $1 \%$. Mortar strength testing was carried out after 3, 7, 14, 21 and 28 days of maintenance

The compressive strength results obtained in each composition of the geopolymer mortar mixture are for geopolymer mortar without a mixture of alumunium powder as large as Mpa, for geopolymer mortar with a mixture of alumunium powder as much as $0.5 \%, 0.75 \%$ and $1 \%$ have a compressive strength of $20.9 \mathrm{Mpa}, 15.2$ Mpa, 12.7 Mpa Dan 9,7 Mpa
\end{abstract}

Keywords:alumunium powder,compressive strength, mortar,geopolymer

\section{INTRODUCTION}

The more advanced and developed the current construction development and the accompanying growth in the occupation rate which is increasingly rapid, the need for facilities and facilities is increasing, especially in the construction of houses, bridges, roads, high-rise buildings and so on. Concrete construction elements are widely used because the raw material is relatively easy to obtain, easy to mold as needed, has high compressive strength and is resistant to weather changes.

Because during the burning of raw materials to produce cement it releases carbon dioxide gas $\left(\mathrm{CO}_{2}\right)$, thereby increasing global heating activity. One way to reduce $\mathrm{CO}_{2}$ (carbon dioxide) emissions is to reduce the use of Portland cement in concrete production, this can be done by using added materials from industrial waste which have the same characteristics as cement. It can also be said that environmentally friendly cement is known as geopolymer.This geopolymer mortar and concrete can be made from raw materials containing silica and aluminum[1].

Geopolymer mortar is a mortar with natural ingredients as a binder which has high alumina and silica oxide content [2]. In the manufacturing process, mortargeopolymers can use natural minerals with high $\mathrm{SiO}_{2}$ (silica oxide) content as precursors, for example palm ash, rice husk ash, fly ash and others. This material does not have the ability to bind, but with activators as a binder such as $\mathrm{NaOH}$ (sodium hydroxide) and $\mathrm{Na}_{2} \mathrm{SiO}_{3}$ (sodium silicate), the silica oxide contained in these materials will react chemically and form polymer bonds..

Fly ash and palm ash are residual ash from combustion which is widely used in industry which becomes waste and thus pollutes the environment. Fly ash and palm ash are potential materials to be developed as a substitute for cement for the manufacture of concrete because they have high silica and aluminum content. [1].

The application of geopolymer lightweight concrete in construction can be an effort to obtain new environmentally friendly concrete. To determine the use of palm ash, Fly Ash and activator solutions and a mixture of aluminum powder on lightweight concrete, a mortar mixture can be tested. There have not been many studies on geopolymer lightweight concrete mixtures so there 
is no mix design that can be used properly.

Kota Pagar Alam is a city of mountains, with a large tea plantation owned by a tea factory managed by PTPN VII. PTPN VII uses waste from oil palm fruit imported from PTVN VII's palm oil plantation itself as fuel for the waste boiler plant in the form of shells, fibers and empty bunches which produce ash, the ash produced from the combustion becomes waste which results in environmental pollution. in the area around the factory.

In Muara Enim Regency, South Sumatra, there is the Bukit Asam PLTU in Tanjung Enim Regency, where the PLTU uses coal which produces waste, namely fly ash. The waste produced at PLTU Bukit Asam is quite a lot which causes environmental pollution, where the waste has not been utilized..

rom the problems found, the researcher wants to do research to reduce environmental pollution due to the use of cement in making concrete besides this research to reduce environmental pollution from the results of factory combustion by utilizing fly ash waste and palm ash as a substitute for cement for making geopolymer light mortar using aluminum powder.

\section{RESEARCH METHODOLOGY}

The method used in this study is to use an experimental method in the laboratory, which aims to determine the optimum amount of use of aluminum powder as a geopolymer lightweight mortar made from fly ash and palm ash.

\subsection{Research Location}

This research was conducted in the concrete laboratory at the High School of Fencealam technology (Sekolah Tinggi Teknologi Pagaralam) which is located at Jl. Masik siagim No.75 simpang mbacang kel. Karang Dalo kec. Dempo Tengah Kota Pagar Alam.

\subsection{Composite Mixture of Test Objects}

The composition of the mixture in this study for the fixed variables used was the ratio of $\mathrm{Na} 2 \mathrm{SiO} 3: \mathrm{NaOH}=2.5: 1$, the ratio of Activator: Precursor $=1: 1$, Fine Aggregate: Frecursor $=1.5$ : 1, the concentration of $\mathrm{NaOH}$ used was $12 \mathrm{M}$ and the addition of aluminum powder as much as 0 , $0.5,0.75$ and $1 \%$. for the ratio of the percentage between fly ash and palm ash is $75: 25 \%$. The test object used is in the form of a $5 \times 5 \times 5 \mathrm{~cm}$ cube. Mixed composition of the Test Object

Table 1. Composition of the geopolymer light mortar mixture

\begin{tabular}{|c|c|c|c|c|c|c|c|}
\hline \multirow[b]{2}{*}{ code } & \multicolumn{2}{|c|}{ Precursor } & \multirow[b]{2}{*}{$\begin{array}{c}\text { Fine } \\
\text { Aggregate } \\
\text { (Gram) }\end{array}$} & \multirow[b]{2}{*}{$\mathrm{NaOH}$} & \multirow[b]{2}{*}{$\mathrm{Na}_{2} \mathrm{SiO}_{3}$} & \multirow[b]{2}{*}{$\begin{array}{l}\text { Aluminum } \\
\text { Powder } \\
\text { (Gram) }\end{array}$} & \multirow[b]{2}{*}{$\begin{array}{c}\text { Number } \\
\text { of Test } \\
\text { Objects }\end{array}$} \\
\hline & $\begin{array}{c}\text { Fly } \\
\text { Ash } \\
\text { (Gram) }\end{array}$ & $\begin{array}{c}\text { palm ash } \\
\text { (Gram) }\end{array}$ & & & & & \\
\hline $\mathrm{Ra} 1$ & 30 & 10 & 120 & 11,4 & 28,6 & 0 & 15 \\
\hline $\mathrm{Ra} 2$ & 30 & 10 & 120 & 11,4 & 28,6 & 0.2 & 15 \\
\hline Ra3 & 30 & 10 & 120 & 11,4 & 28,6 & 0.3 & 15 \\
\hline Ra4 & 30 & 10 & 120 & 11,4 & 28,6 & 0.4 & 15 \\
\hline \multicolumn{7}{|c|}{ Total Number of Test Objects } & 60 \\
\hline
\end{tabular}

\subsection{The tools used}

The tools used in this study are as follows:

1. A set of filters and vibrators

2. Weighing equipment is used to weigh the mortar, to an accuracy of 0.1 gram

3. Measuring cup is $100 \mathrm{ml}$ and $1000 \mathrm{ml}$, respectively 
4. Bucket as a tool for taking and holding water

5. Cups and basins as a place for preparing mortar stacking materials

6. Mortar compressive strength testing machine

7. The specimen is cuboid with size $5 \times 5 \times 5 \mathrm{~cm}$

8. Mixer machine

9. Spatula (cement spoon) as a means of leveling the concrete mixture

10. The compactor in the form of iron to compact the mortar mixture

\subsection{Fine aggregate testing}

For the examination of fine aggregates in the preparation of a light mortar for geopolymer palm ash and Fly Ash using aluminum powder as follows:

1. Grading fine aggregate testing

Testing of fine aggregates in this study is based on SNI [3].

2. Testing of fine aggregate sludge content

Testing of aggregate sludge content in this study is based on SNI[4].

3. Testing of organic content

Testing of aggregate organic content based on SNI [5].

4. Density test for aggregate

Aggregate density testing based on SNI [6].

\subsection{Preparation of Alkali Activator solution}

\section{NAOH solution}

$\mathrm{NaoH}$ (Sodium Hydroxide) is used to react $\mathrm{Al}$ and Si Elements by Adding $\mathrm{Na}$ Ion[7].So that it can produce a strong polymer bond. The higher the mole value of $\mathrm{NaOH}$, the more $\mathrm{OH}$ - ions that can be used to react with $\mathrm{Si}$ and $\mathrm{Al}$, so that the compressive strength increases [8].In this study, $\mathrm{NaOH}$ was used in the form of crystals so that it had to be liquefied by means of distilled water. The preparation of a $12 \mathrm{M} \mathrm{NaOH}$ solution can be calculated using the following equation.

Aquades water is planned as much as 1 liter, so that:

$$
\begin{aligned}
& \text { Molaritas }=\frac{\text { gram }}{M r ~ N a O H} \times \frac{1000}{m l} \\
& \mathrm{Mr} \mathrm{NaOH}=\mathrm{Ar} \mathrm{Na}+\mathrm{ArO}+\mathrm{ArH}=23+16+1=40 \\
& \text { Gram NaOH } 12 \mathrm{M} \text { in } 1000 \mathrm{ml}=480 \text { gram }
\end{aligned}
$$

\section{The ratio of $\mathrm{Na}_{2} \mathrm{SiO}_{3}: \mathrm{NaOH}$}

In its development, silicates can be used for various purposes, including for cement mixtures, ceramic binders, coatings, paint mixes and in several industrial purposes such as paper, textiles and fibers[9].

he weight ratio of $\mathrm{Na} 2 \mathrm{SiO} 3: \mathrm{NaOH}$ used is 2.5: 1.Thus, it produces:

$\begin{array}{ll}\mathrm{NaOH} \text { weight } & =1480 \mathrm{gram} \\ \text { Weight of Na2SiO3 }=1480 \times 2.5 & =3700 \mathrm{gram} \\ \text { Weight of the alkaline activator solution } & =5180 \mathrm{gram}\end{array}$

\subsection{Preparation of Mortar Geopolymer Specimens}

The sand and precursors are mixed first. The material that has been mixed is then stirred with a mixer, put the sand (fine aggregate) and precursor into the mixer, stir dry for three minutes starting at slow speed until well blended, then enter the mixed $\mathrm{NaOH}$ and $\mathrm{Na} 2 \mathrm{SiO} 3$ solution then stir at medium speed for 5 minutes. After that continue at high speed for 10 minutes [10]. 


\subsection{Printing of Test Objects}

The test object used was a $5 \times 5 \times 5 \mathrm{~cm}$ cube, each sample had 3 specimens with each of these variations. Three samples were made to test the strength of the mortar for 3, 7, 14, 21 and 28 days.

\subsection{Treatment of Test Objects}

Treatment of mortar specimens is divided into two, namely treatment / curing using an oven and treatment / curing of air or room temperature. In this study I used air curing or room temperature curing where the mortar was stored in the test object storage room at room temperature, which was previously left in the mold for 24 hours. Mortar treatment in this study is as follows.

1. Treatment is carried out until the age of 3 days to test the compressive strength of the mortar aged 3 days.

2. Treatment is carried out until the age of 7 days for a mortar compressive strength test of 7 days

3. Treatment is carried out until the age of 14 days to test the compressive strength of the mortar at the age of 14 days.

4. Treatment is carried out until the age of 21 days to test the compressive strength of the mortar at the age of 21 days

5. The treatment is carried out until the age of 28 days to test the compressive strength of the mortar at the age of 28 days.

\subsection{Testing mortar specimens}

1. Testing the specific gravity of the mortar

Mortar density testing based on SNI [11].

2. Testing the compressive strength of the mortar

Testing of mortar compressive strength based on SNI [11].

\section{RESULTS AND DISCUSSION}

\subsection{Grading inspection of fine aggregates}

Examination of fine aggregate grading aims to determine variations in grain diameter and modulus of fineness. The tool used is a sieve that has been arranged in the order of the sieve holes, then the test object is inserted in the form of sand weighing 500 grams.

Table 2. Results of fine aggregate inspection

\begin{tabular}{cccccc}
\hline $\begin{array}{c}\text { Filter } \\
\text { Number }\end{array}$ & $\begin{array}{c}\text { Filter Size } \\
(\mathbf{m m})\end{array}$ & $\begin{array}{c}\text { Restrained } \\
\text { Weight } \\
\text { (gram) }\end{array}$ & $\begin{array}{c}\text { Percent } \\
\text { Withheld (\%) }\end{array}$ & $\begin{array}{c}\text { Cumulative on hold } \\
\mathbf{( \% )}\end{array}$ & $\begin{array}{c}\text { Cumulative Weight } \\
\text { Withheld Through the } \\
\text { Filter } \\
\text { (\%) }\end{array}$ \\
\hline 4 & 4,75 & 0 & 0 & 0 & 100 \\
10 & 2 & 10 & 2 & 2 & 98 \\
20 & 0.85 & 30 & 6 & 8 & 92 \\
40 & 0.425 & 45 & 9 & 17 & 83 \\
60 & 0.25 & 75 & 15 & 32 & 68 \\
100 & 0.15 & 190 & 38 & 70 & 30 \\
200 & 0.075 & 105 & 21 & 91 & 9 \\
Pan & - & 45 & 9 & 100 & 0 \\
\hline
\end{tabular}

Fine Modulus of Fine Aggregate Grains $=\frac{\text { cumulative on } \text { hold }}{100}=\frac{320}{100}=3.2$ 
The test results showed that the fine modulus of fine aggregate was 3,2. This is in accordance with the SNI requirements [12]. namely the fine modulus of grains between $1.5-3.8$ so that the fine aggregate meets the existing conditions.

\subsection{Content of Fine Aggregate Sludge}

The analysis of sludge content aims to determine whether the content of mud in the sand meets the minimum standard of fine aggregate requirements. The test results can be seen the following image
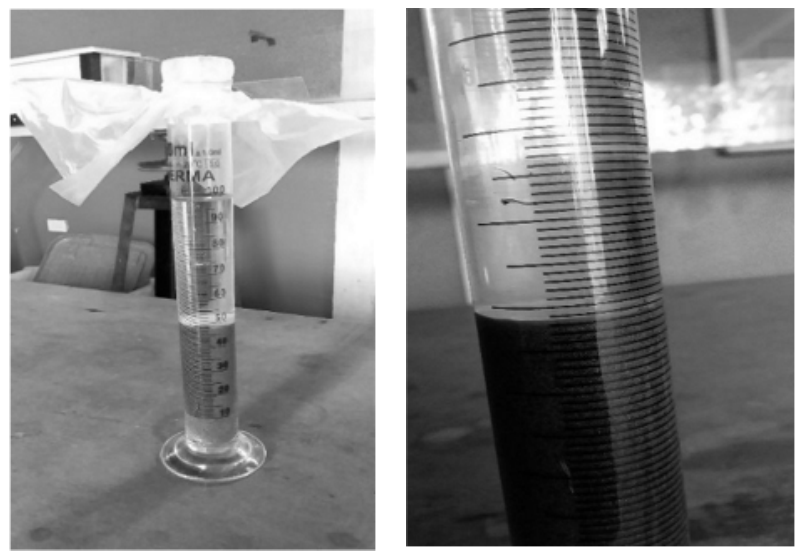

Figure 1. The results of the aggregate sludge content test

Analysis of fine aggregate sludge content is:

$\begin{array}{ll}\text { Sand } & =48 \mathrm{ml} \\ \text { Origin } & =\text { Lematang River, City of Pagar Alam } \\ \text { Sediment volume } & =1 \mathrm{ml}\end{array}$

Mud content in fine aggregate $=\frac{1}{49} \times 100 \%=2,04 \%$

Lematang river sand silt content is $2.04 \%$ based on the analysis results can be used to make mortar because it meets the requirements of SK SNI S-04-1989-F, namely the value of sludge content $<5 \%$

\subsection{Aggregate density check}

Density test for fine aggregate is done by using aggregate as much as 50 grams. The results of the density of fine aggregate SSD can be calculated to find out the value by the calculation below.

Fine aggregate $=50$ gram

Origin = Lematang River, City of Pagar Alam

Aggregate Weight + measuring cup + Water $=254$ gram

$\mathrm{SSD}$ weight $\quad=50$ gram

Measuring Cup Weight + Water = 223 gram

SSD aggregate density $=\frac{50}{(223+50)-254}$

$=2,6 \mathrm{~g} / \mathrm{cm}^{3}$

Based on the General Requirements for Building Materials in Indonesia (PUBI-1928), the specific gravity of good sand is $2.4-2.9$

\subsection{Aggregate Organic Level Examination}


Examination of the organic content of fine aggregates aims to obtain a number with the instructions for the standard solution or the predetermined color standard of the sand specimen solution.

Tabel 3. Prof. Rosseno Standar ASTM C-40-79

\begin{tabular}{cc}
\hline $\begin{array}{c}\text { Mixed Color } \\
\text { water }=\mathbf{N a O H}\end{array}$ & Organic Substance Content \\
\hline Clear & $0 \%$ \\
Light yellow & $0-10 \%$ \\
Dark yellow & $10-20 \%$ \\
Reddish yellow & $20-30 \%$ \\
Reddish brown & $30-40 \%$ \\
Dark brown & $50-100 \%$ \\
\hline
\end{tabular}

From the results of testing the organic content of lematang sand, Pagar Alam town was carried out by visually showing the color of the light yellow measuring tube, which means that the organic substance content is $0-10 \%$ so that the fine aggregate used during the polyzimization process does not absorb the activator alkaline solution. Can be seen in Figure 2.

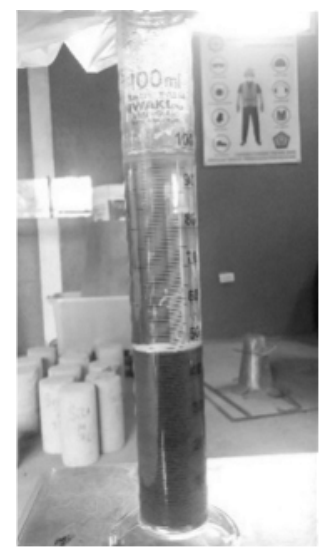

Figure 2. The results of the aggregate organic content test

\subsection{Mortar Density Analysis}

The results of the mortar specific gravity test can be seen in table 4 and Figure 3 below:

Table 4. The results of the mortar specific gravity test

\begin{tabular}{ccccccc}
\hline \multirow{2}{*}{ NO } & \multirow{2}{*}{ CODE } & \multicolumn{5}{c}{ Specific gravity $\left(\mathbf{g r} / \mathbf{c m}^{\mathbf{3}}\right)$} \\
\cline { 3 - 7 } & & $\mathbf{3}$ & $\mathbf{7}$ & $\mathbf{1 4}$ & $\mathbf{2 1}$ & $\mathbf{2 8}$ \\
\hline 1 & $\mathrm{Ra} 1$ & 1,90 & 1,88 & 1,89 & 1,91 & 1,94 \\
2 & $\mathrm{Ra} 2$ & 1,87 & 1,84 & 1,86 & 1,87 & 1,89 \\
3 & $\mathrm{Ra} 3$ & 1,86 & 1,82 & 1,83 & 1,85 & 1,88 \\
4 & $\mathrm{Ra3}$ & 1,81 & 1,78 & 1,81 & 1,82 & 1,85 \\
\hline
\end{tabular}

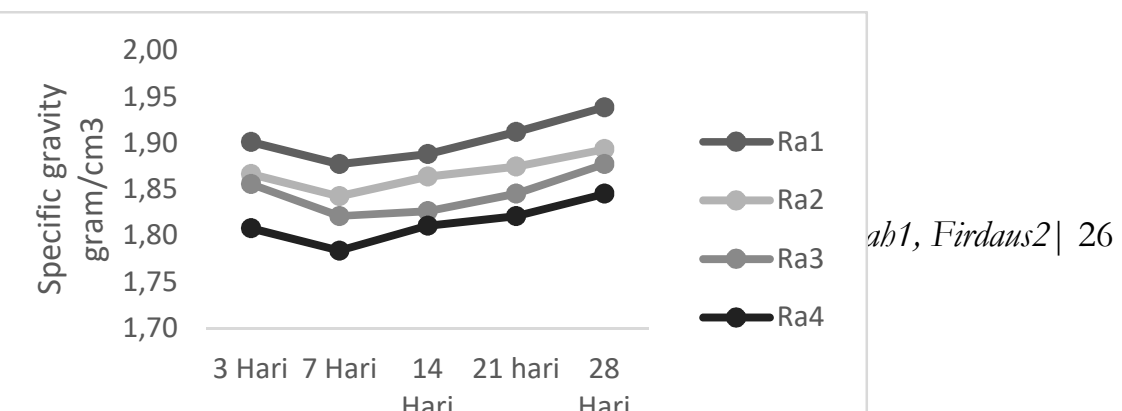


Figure 3. The results of the mortar specific gravity test

Based on table 4 and Figure 3, the specific gravity test results of fly ash geopolymer mortar and palm ash have increased their specific gravity because the longer time makes the polymerization reaction maximum, resulting in stronger and denser bonds. The highest weight is obtained in the composition of the mortar geopolymer mixture not using aluminum powder at the age of 28 days with the code Ra1 the weight obtained is 1.94 grams / cm3 while the lightest is in the composition of mortar using aluminum powder as much as $1 \%$ at 28 days with Ra 4 of 1.85 gram / cm 3 from these results shows that the more aluminum powder is used, the lighter the mortar is obtained. Because by adding aluminum powder to the mixture, a chemical reaction will occur which releases a certain amount of gas, and after mixing the hardener a porous structure will form so that it is lighter, the more aluminum powder is added, the more gas and pores that are formed, resulting in lighter mortar.

\subsection{Mortar Compressive Strength Analysis}

The results of the mortar compressive strength test can be seen in Table 5 and Figure 4 below:

Table 5. The results of the mortar compressive strength test

\begin{tabular}{ccccccc}
\hline \multirow{2}{*}{ NO } & \multirow{2}{*}{ KODE } & \multicolumn{5}{c}{ Mpa } \\
\cline { 3 - 7 } & & $\mathbf{3}$ & $\mathbf{7}$ & $\mathbf{1 4}$ & $\mathbf{2 1}$ & $\mathbf{2 8}$ \\
\hline 1 & $\mathrm{Ra} 1$ & 9,5 & 9,9 & 13,6 & 16,3 & 20,9 \\
2 & $\mathrm{Ra} 2$ & 4,9 & 6,5 & 9,9 & 12,4 & 15,2 \\
3 & $\mathrm{Ra} 3$ & 3,6 & 5,6 & 8,5 & 10,1 & 12,7 \\
4 & $\mathrm{Ra} 4$ & 3,1 & 4,3 & 5,7 & 6,4 & 9,7 \\
\hline
\end{tabular}

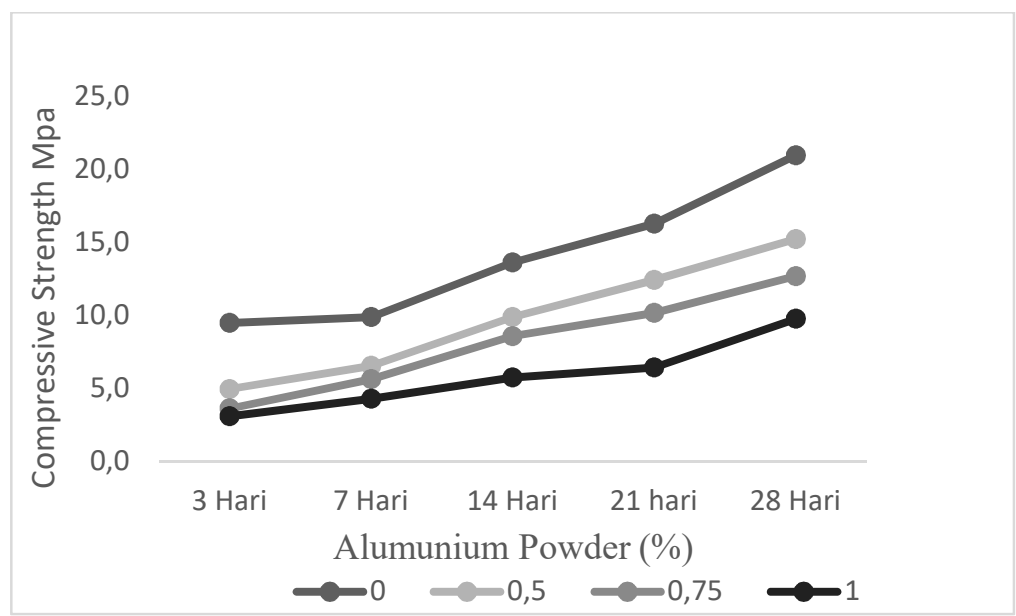

Figure 4. The results of the mortar compressive strength test

Seen in Figure 4 and table 5, the maximum compressive strength of 28 days in the composition of the geopolymer mortar mixture not using aluminum powder is $20.9 \mathrm{Mpa}$ while the lowest mortar compressive strength is still in the composition of the geopolymer mortar mixture using aluminum 
powder as much as $1 \%$ as much as $9.7 \mathrm{Mpa}$. Geopolymer mortar requires a long time to polymerize, the compressive strength is increasing frequently the testing time.

The relationship between the compressive strength of the mortar and age shows that the longer the treatment time for the test object, the higher the compressive strength obtained, the maximum compressive strength obtained at the age of 28 days is the test object with the composition of a geopolymer mortar mixture without using aluminum powder with a code of Ra1 of $20.9 \mathrm{Mpa}$, geopolymer mortar requires a maximum polymerization time so that the age of 28 days the compressive strength obtained is maximum and the lowest compressive strength (minimum) is a mixture of geopolymer mortar using aluminum powder as much as 1\% with a code of Ra4 of 9.7 $\mathrm{Mpa}$. The results of this test show that the more aluminum powder is used, the lower the compressive strength obtained. There was a significant decrease in each composition mixture with the addition of aluminum powder. This is because the elements contained in the aluminum powder which produce gas make the mortar produce a lot of pores.

\subsection{The Relationship between Density And Mortar Compressive Strength}

For the relationship between specific gravity and compressive strength of mortar can be seen in the following table:

Table 6. Relationship between specific gravity and compressive strength of mortar

\begin{tabular}{cccc}
\hline No & Code & $\begin{array}{c}\text { Mortar density } \\
\left(\text { gram/ } / \mathbf{c m}^{3}\right)\end{array}$ & $\begin{array}{c}\text { Compressive } \\
\text { strength } \\
\text { (MPa) }\end{array}$ \\
\hline 1 & Ra1 & 1,9387 & 20,9 \\
2 & Ra2 & 1,8933 & 15,2 \\
3 & Ra3 & 1,8773 & 12,7 \\
4 & Ra4 & 1,8453 & 9,7 \\
\hline
\end{tabular}

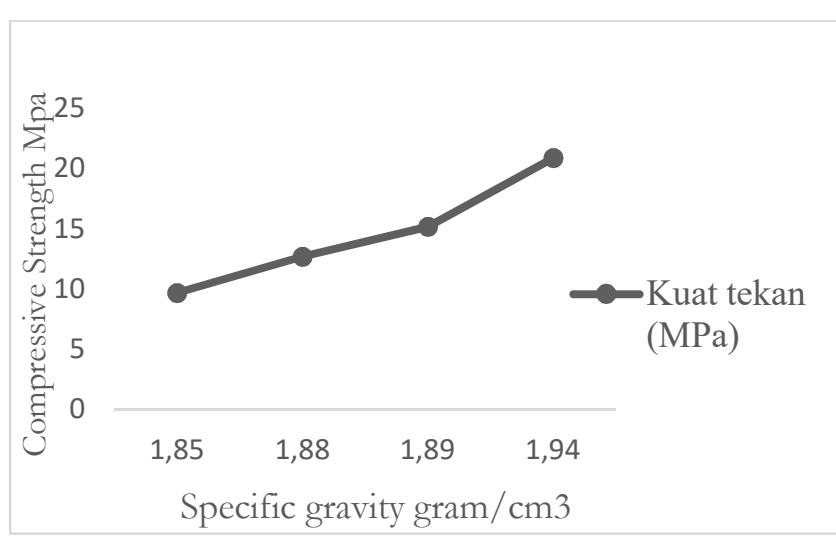

Figure 5. Relationship between compressive strength and mortar density

Based on the table 6 and Figure 5, the test results of the geopolymer mortar compressive strength are directly proportional to its specific gravity, the heavier the geopolymer mortar the higher the compressive strength. Conversely, the lighter the density of the mortar, the lower the compressive strength obtained. The aluminum powder used affects the weight and compressive strength of the geopolymer mortar. 


\section{CONCLUSION}

Based on the results and discussion of this study, several conclusions were obtained, namely;

1. For a geopolymer mortar made from fly ash and palm ash with a ratio of $75: 25 \%$, the maximum compressive strength is $20.9 \mathrm{Mpa}$.

2. For lightweight geopolymer mortar made from fly ash and palm ash with the addition of $0.5 \%$ powdered aluminum powder as much as $15.2 \mathrm{Mpa}$

3. For light mortar geopolymer made from fly ash and palm ash with the addition of aluminum powder slurry as much as $0.75 \%$ of $12.7 \mathrm{Mpa}$

4. For light mortar geopolymer made from fly ash and palm ash with the addition of aluminum powder as much as $1 \%$ of $9.7 \mathrm{Mpa}$

\section{REFERENCES}

[1] P. S. D. Geologi, "Badan Geologi Kementerian Energi dan Sumber Daya Mineral (ESDM)," Sumber Daya dan Cadangan Miner. Bukan Logam dan Batuan, 2014.

[2] B. DWIKA A, "PENGARUH PERBANDINGAN WATER SOLID RATIO (W/S) TERHADAP KUAT TEKAN DAN KUAT LEKAT MORTAR GEOPOLYMER BERBAHAN DASAR ABU TERBANG DENGAN NaOH 12 M PADA SUHU RUANGAN,” Rekayasa Tek. Sipil, vol. 2, no. 2/REKAT/17, 2017.

[3] B. S. Nasional, "Tentang Tata Cara Pembuatan Rencana Campuran Beton Normal," SNI, vol. 3, p. 2834, 2000.

[4] P. Purwanto and Y. A. Priastiwi, "Pengaruh Kadar Lumpur Pada Agregat Halus Dalam Mutu Beton," Teknik, vol. 33, no. 2, pp. 46-51, 2012.

[5] B. S. Nasional, "SNI 2816: 2014 Metode Uji Bahan Organik dalam Agregat halus untuk beton." Jakarta: Badan Standarisasi Nasional, 2014.

[6] S. N. Indonesia, "Metode pengujian berat jenis dan penyerapan air agregat kasar," SNI-031969-1990, 1990.

[7] T. Utomo, "Analisa Kuat Tekan Beton Geopolimer Dengan Bahan Alternatif Abu Sekam Padi Dan Kapur Padam.” Teknik Sipil-Fakultas Teknik, 2017.

[8] R. D. Fransiska, "PENGARUH RASIO PREKURSOR: AKTIVATOR TERHADAP KUAT TEKAN MORTAR GEOPOLIMER ABU SEKAM PADI," J. Ilm. BERING'S, vol. 6, no. 01, pp. 32-36, 2019.

[9] D. Hardjito and B. V. Rangan, "Development and properties of low-calcium fly ash-based geopolymer concrete," 2005.

[10] S. Thokchom, P. Ghosh, and S. Ghosh, "Performance of fly ash based geopolymer mortars in sulphate solution," J. Eng. Sci. Technol. Rev., vol. 3, no. 1, pp. 36-40, 2010.

[11] B. S. Nasional, "Metode pengujian kekuatan tekan mortar semen Portland untuk pekerjaan sipil," SNI 03-6825-2002, Indonesia, 2002.

[12] B. S. Nasional, "SNI 03-1968-1990," Metod. Penguji. Anal. Saringan Agreg. Halus dan Kasar, 1990. 